\title{
Vacuum-assisted Biopsy and Steroid Therapy for Granulomatous Lobular Mastitis: Report of Three Cases
}

Sayaka Kuba ${ }^{1}$, Junzo Yamaguchi ${ }^{1}$, Hiroshi Ohtani ${ }^{2}$, Isao Shimokawa ${ }^{2}$, Shigeto Maeda ${ }^{3}$ and Takashi Kanematsu ${ }^{3}$

${ }^{1}$ Department of Surgery, National Hospital Organization, Saga, Japan

${ }^{2}$ Departments of Investigative Pathology and ${ }^{3}$ Surgery, Graduate School of Biomedical Sciences, Nagasaki University, Nagasaki, Japan.

Reprint requests to: S. Kuba

Department of Surgery, Graduate School of Biomedical Sciences, Nagasaki University

1-7-1 Sakamotomachi, Nagasaki, 852-8501, Japan,

TEL : 8195-849-7316

FAX: 8195-849-7319

e-mail: sayaka315@vesta.ocn.ne.jp

Running head: Vacuum-assisted Biopsy and Steroids for GLM

ST-2007-1003-CR.RI 


\begin{abstract}
We report the cases of three patients with granulomatous lobular mastitis (GLM), who were treated successfully with low-dose steroid therapy. Furthermore, the findings of our review of 271 patients reported in the literature suggest that steroid therapy is the treatment of choice for GLM.
\end{abstract}

Key words: Granulomatous lobular mastitis

Vacuum-assisted biopsy

Steroid therapy 


\section{Introduction}

Granlomatous lobular mastitis (GLM) is a chronic inflammatory disease of the breast with the natural history of a self-limiting condition. However, the disease is occasionally confused with malignancy, with reports of mastectomy or chemotherapy being performed. ${ }^{1-7}$ Therefore, thorough tissue examination is a prerequisite for the differential diagnosis of GLM. ${ }^{8} \quad$ Ultrasonography (US) guided vacuum-assisted biopsy, Mammotome breast biopsy system, (Ethicon Endo-Surgery, [Johnson \& Johnson], Cincinnati, OH, USA), a relatively non-invasive and safe procedure, has become popular in the last decade. ${ }^{9,10}$ There is still no consensus on the optimal treatment for GLM, although wide excision of the breast mass seems to be the procedure of choice. We treated GLM successfully in three women and present this report to explore the treatment strategies, based on our review of reported patients. 


\section{Case Reports}

\section{Case 1}

A 38-year-old woman presented with a tender lump in her left breast. The patient had two children. Physical examination revealed a firm, ill-defined mass, $5 \mathrm{~cm}$ in size, in the left breast. Ultrasonography showed a hypoechoic ill-defined mass, whereas magnetic resonance imaging (MRI) showed well-enhanced diffuse nodules with early enhancement, implying malignant disease. Vacuum-assisted biopsy revealed marked inflammatory infiltrate centering on lobules in the breast (Fig. 1a). The lesion consisted of lymphocytes, plasma cells, neutrophils, eosinophils, and epithelioid histiocytes with frequent granuloma formation. The severely affected lesion developed in a diffuse confluent fashion and the involved epithelial components were entirely destroyed. Gram and Grocott staining for organisms was negative. These findings were consistent with a diagnosis of idiopathic GLM. The patient was treated with aspiration and drainage of an abscess, as well as corticosteroid (prednisone 5-2.5 mg/day) for 4 months. No recurrence has been observed

\section{Case 2}

A 35-year-old woman presented with a left breast mass. She had one child and suffered from Graves’ disease, but her thyroid function was regulated with oral medication. Physical examination revealed a firm, ill-defined mass, $6 \mathrm{~cm}$ in size, in the left breast. Specimens obtained from vacuum-assisted biopsy showed granulomatous lobulitis histologically (Fig. 1b). An abscess was drained repeatedly when the patient suffered breast pain, but the breast lesion did not disappear. Steroid therapy (5-2.5 mg/day) was started 8 months after the initial appearance of symptoms, and 2 months later the breast mass had shrunk dramatically and the medication was discontinued. No recurrence has been observed for 30 months. 


\section{Case 3}

A 25-year-old woman presented with a painful right breast mass. There was no history of fever or nipple discharge. She had one child. Physical examination revealed a firm, ill-defined mass, $7 \mathrm{~cm}$ in size, in the right breast. Ultrasonography showed a hypoechoic mass and abscess formation. The diagnosis of GLM was based on the findings of a vacuum-assisted biopsy (Fig. 1c). Despite repeated drainage of an abscess (aspiration or mini-incision), the symptoms had not resolved after 2 months. No organisms were isolated from the abscess fluid. Oral prednisone, $5 \mathrm{mg} /$ day, was given for 3 weeks and the dose was increased to $10 \mathrm{mg} /$ day when no reduction in the breast mass was observed. The breast symptoms had markedly improved within 6 weeks, and the steroid dose was gradually reduced. No further recurrence has been observed in the 5 months since steroid therapy was discontinued.

None of the three women have any breast deformity.

\section{Discussion}

Our search of the English medical literature found reference to 271 patients diagnosed with GLM. ${ }^{1-8,11-51}$ These patients ranged in age from 11 to 80 years (mean, 35 years) and 96\% (174/181) were multiparous women. The cause of GLM is unknown, but it could be related to age and pregnancy. Establishing a correct diagnosis is not easy, and it is especially difficult to distinguish GLM from malignancy. In fact, 51\% (101/196) of the reported pretreatment diagnoses were malignant, and the final diagnosis was made by histological examinations. On the other hand, fine-needle aspiration cytology was done for 14 patients, revealing suspicious and malignant cytology in four and three patients, respectively, resulting in radical mastectomy or chemotherapy in seven patients. ${ }^{1-7}$ Histological examination is considered essential for the accurate diagnosis of GLM. We now perform US-guided vacuum-assisted biopsy to identify the lobular distribution pattern because specimens can be collected easily and abundantly. Vacuum-assisted biopsy has excellent sensitivity and specificity for the diagnosis of 
breast diseases. ${ }^{9,10}$

The optimal therapy for this condition remains unclear. Wide excision of the breast mass has been performed traditionally, the justification for this being that it achieves an accurate diagnosis by sufficient tissue examination. As shown in Table 1, 248 patients were available for evaluation of treatment strategy. Excision or wide excision was performed in 172 patients, steroid therapy in 31 patients including ours, and drainage in 25 patients. Total mastectomy was performed in six patients. We investigated the clinical outcome of patients treated with surgery, corticosteroid, and drainage and were able to review of the outcome of surgical treatment in 144. Thirty-four patients suffered recurrence after surgical treatment [23.6\%]), and 10 experienced complications (Table 2.). Meanwhile, recurrent disease was observed after steroid therapy in eight patients (25.8\%), but all of these patients were cured thereafter by repeated steroid treatment. ${ }^{23,38,48}$ Thus, an excellent outcome without surgical intervention was achieved in 29 (93.5\%) patients.

A summary of the 31 patients who received steroid therapy is presented in Table 3. From 1980 to 2000, most patients received steroid therapy at an initial dose of 60 $\mathrm{mg} /$ day, which was gradually reduced for 2 to 11 months. We treated all of our three patients successfully with a low dose of steroids without any toxicity, although all required abscess drainage to alleviate the breast symptoms. Wilson et al. recently reported a therapeutic paradigm based on an analysis of reported cases $(n=116)$. They stated that for patients with localized disease and mild symptoms, observation or local excision is warranted. Although recurrence sometimes developed after steroid therapy, we propose that steroid therapy is effective, because patients responded well to another courses of steroids.

In conclusion, vacuum-assisted biopsy is useful way to avoid unnecessary treatment. Based on the findings of the present detailed investigation, we propose that steroid therapy should be the treatment of choice for GLM. 
Table1. Treatments for granulomatous lobular mastitis.

\begin{tabular}{lc}
\hline & $\begin{array}{c}\text { Number of cases } \\
(\mathrm{n}=248)\end{array}$ \\
\hline excision or wide excision & 172 \\
corticosteroids & 31 \\
drainage only & 25 \\
mastectomy & 6 \\
others & $14^{\mathrm{a}}$ \\
\hline
\end{tabular}

${ }^{a}$ Seven of these patients underwent excision and steroid therapy. 
Table 2. Outcome of primary excision and steroid therapy for granulomaous lobular mastitis.

\begin{tabular}{|c|c|}
\hline Clinical outcome & Number of patients \\
\hline \multicolumn{2}{|l|}{ Excision $(n=144)$} \\
\hline Cure & 100 \\
\hline Recurrence & 34 \\
\hline Wound infection & 7 \\
\hline Persistent inflammation & 3 \\
\hline \multicolumn{2}{|l|}{ Steroid therapy $(n=31)^{a}$} \\
\hline Cure & 21 \\
\hline Recurrence & 8 \\
\hline Reduction & $2^{b}$ \\
\hline \multicolumn{2}{|l|}{ Drainage $(n=25)$} \\
\hline No change & 6 \\
\hline Persistant inflammation & 5 \\
\hline Recurrence & 4 \\
\hline Deformity & 1 \\
\hline Unknown & 9 \\
\hline
\end{tabular}

${ }^{\mathrm{a}}$ Including our three patients.

${ }^{\mathrm{b}}$ Two patients underwent breast surgery. 
Table 3. Thirty-one patients treated with corticosteroid therapy

\begin{tabular}{|c|c|c|c|c|c|c|}
\hline \multirow[t]{2}{*}{ No. } & \multirow[t]{2}{*}{ Year } & \multicolumn{2}{|c|}{ Age Mass size } & \multicolumn{2}{|l|}{ Steroid therapy } & \multirow[t]{2}{*}{ final outcome } \\
\hline & & & size $(\mathrm{cm})$ & dose $(\mathrm{mg}) *$ & period & \\
\hline 1 & $1980(\underline{15})$ & 27 & 9 & 60 & $4 \mathrm{M}^{\#}$ & cure \\
\hline 2 & $1992(\underline{23})$ & 41 & 5 & 60 & $13 \mathrm{M}$ & recurrence \\
\hline 3 & & 36 & - & 60 & $6 \mathrm{M}$ & cure \\
\hline 4 & $1994(\underline{24})$ & 36 & 10 & 60 & $2 \mathrm{M}$ & reduction \\
\hline 5 & $1995(\underline{27})$ & 43 & 6.5 & 37.5 & $3 W^{\$}$ & cure \\
\hline 6 & 1996 (ㅁ) & 34 & 8 & 60 & $11 \mathrm{M}$ & cure \\
\hline 7 & $2000(36)$ & - & - & - & $3 \mathrm{M}$ & cure \\
\hline 8 & & - & - & - & $3 \mathrm{M}$ & cure \\
\hline 9 & 2000 (37) & 25 & 2 & 60 & $5 \mathrm{M}$ & recurrence \\
\hline 10 & 2001 (39) & 25 & 12 & 10 & $3.5 \mathrm{M}$ & cure \\
\hline 11 & $2001(40)$ & 37 & - & 32 & - & reduction \\
\hline 12 & $2003(46)$ & 46 & 5 & 30 & $2 \mathrm{~W}$ & cure \\
\hline $13-1$ & 82003 (47) & & & 60 & & cure \\
\hline $19-2$ & 42003 (47) & & & 60 & & recurrence \\
\hline 25 & 2004 (49) & - & - & - & - & cure \\
\hline 26 & & - & - & - & - & cure \\
\hline 27 & & - & - & - & - & cure \\
\hline 28 & & - & - & - & - & cure \\
\hline 29 & present case & 38 & 5 & 5 & $4 \mathrm{M}$ & cure \\
\hline 30 & & 35 & 6 & 5 & $2 \mathrm{M}$ & cure \\
\hline 31 & & 25 & 7 & 10 & $5 \mathrm{M}$ & cure \\
\hline
\end{tabular}

*initial dose of prednisone

\#month

\$week 


\section{References}

1. Kasantikul V. Granulomatous mastitis: case report and review of literature. J Med Assoc Thai 1992; 75: 310-313.

2. Imoto S, Kitaya T, Kodama T, Hasebe T, Mukai K. Idiopathic granulomatous mastitis: case report and review of the literature. Jpn J Clin Oncol 1997; 27: 275-277.

3. Kfoury H, Al Bhlal L. Granulomatous lobular mastitis: a clinicopathological study of 12 cases. Ann Saudi Med 1997; 17: 43-46.

4. Bani-Hani KE, Yaghan RJ, Matalka II, Shatnawi NJ. Idiopathic granulomatous mastitis: time to avoid unnecessary mastectomies. Breast J 2004; 10: 318-322.

5. Tokunaga E, Kimura Y, Kitamura K, Maehara Y. Granulomatous lobular mastitis misdiagnosed as breast carcinoma. Breast J 2004; 10: 261-262.

6. Heer R, Shrimankar J, Griffith CDM. Granulomatous mastitis can mimic breast cancer on clinical, radiological or cytological examination: a cautionary tale. The Breast 2003; 12: 283-286.

7. Kim J, Tymms KE, Buckingham JM. Methotrexate in the management of granulomatous mastitis. Aust N Z J Surg 2003; 73: 247-249.

8. Sato N, Yamashita H, Kozaki N, Watanabe Y, Ohtsuka T, Kuroki S. et al. Granulomatous mastitis diagnosed and followed up by fine-needle aspiration cytology, and successfully treated by corticosteroid therapy: report of a case. Surg Today 1996; 26: 730-733.

9. Kettritz U. Stereotactic vacuum-assisted breast biopsy in 2874 patients. Cancer 2004; 100: 245-51.

10. Pfal G. Stereotactic 11-gauge vacuum- assisted breast biopsy: A validation study. Am J Roentgenol 2002; 179: 1503-1507.

11. Kessler E, Wolloch Y. Granulomatous Mastitis: a lesion clinically simulating carcinoma. Am J Clin Pathol 1972; 58: 642-646.

12. Koelmeyer TD, MacCormick DEM. Granulomatous mastitis. Aust N Z J Surg 1976; 
46: 173-176.

13. Cohen C. Granulomatous mastitis. a review of 5 cases. S Afr Med J 1977; 52: 14-16.

14. Brown KL, Tang PHL. Postlactational tumoral granulomatous mastitiss: a localized immune phenomenon. Am J Surg 1979; 138: 326-329.

15. DeHertogh DA, Rossof AH, Harris AA, Egnomou SG. Predonisone management of granulomatous mastitis. N Engl J Med 1980; 303: 799-800.

16. Carmalt HL, Ramsey-Stewart G. Granulomatous mastitis. Med J Aust 1981; 1: 356-359.

17. Fletcher A, Magrath IM, Riddell RH, Talbot IC. Granulomatous mastitis: a report of seven cases. J Clin Pathol 1982; 35: 941-945.

18. Rowe P. Granulomatous mastitis associated with a pituitary prolactinoma. Br J Clin Pract 1984; 38: 32-34.

19. Going JJ, Anderson TJ, Wilkinson S, Chetty U. Granulomatous loblar mastitis. J Clin Pathol 1987; 40: 535-540.

20. Osborne BM. Granulomatous mastitis caused by Histoplasma and mimicking inflammatory breast carcinoma. Hum Pathol 1989; 20: 47-52.

21. Galea MH, Robertoson JFR, Eliss IO, Elston CW, Blamey RW. Granulomatous loblar mastitis. Aust N Z J Surg 1989; 59: 547-550.

22. Macansh S, Greenberg M, Barraclough B, Pacey F. Fine needle aspiration cytology of granulomatous mastitis: report of a case and review of the literature. Acta Cytol 1990; 34: 38-42.

23. Jorgensen MB, Nielsen DM. Diagnosis and treatment of granulomatous mastitis. Am J Med 1992; 93: 97-101.

24. Donn W, Rebbeck P, Wilson C, Gilks B. Idiopathic granulomatous mastitis: a report of three cases and review of the literature. Arch Pathol Lab Med 1994; 118: 822-825.

25. Howell JD, Barker F, Gazet CJ. Granulomatous lobular mastitis: report of a further two cases and a comprehensive literature review. Breast J 1994; 3: 119-123. 
26. Salam IMA, Alhomsi MF, Daniel MF, Sim AJW. Diagnosis and treatment of granulomatous mastitis. Br J Surg, 1995; 82: 241.

27. Miliauskas JR, Pieterse AS, Williams RS. Granulomatous lobular mastitis. Aust N Z J Surg 1995; 65: 139-141.

28. Kumarasinghe MP. Cytology of granulomatous mastitis. Acta Cytol 1997; 41: 727-730.

29. Van Ongeval C, Schraepen T, Van Steen A, Baert AL, Moerman P. Idiopathic granulomatous mastitis. Eur Radiol 1997; 7: 1010-1012.

30. Martinez-Parra D, Nevado-Santos M, Melendez-Guerrero B, Galcia-Solano J, Perez-Guilman M. Utility of fine-needle aspiration in the diagnosis of granulomatous lesion of the breast. Diagn cytopathol 1997; 17: 108-114.

31. Kobayashi T, Sugihara H, Kato M, Watanabe S. Cytologic features of granulomatous mastitis. Report of a case with fine needle aspiration cytology and immunocytochemical findings. Acta Cytol 1998; 42: 716-720.

32. Cserni G, Szajki K. Granulomaotus lobular mastitis following drug-induced galactorrhea and blunt trauma. Breast J 1999; 5: 398-403.

33. Han BK, Choe YH, Park LM, Moon WK, Ko YH, Yang JH et al. Granulomatous mastitis: mammographic and sonographic appearances. Am J Roentgenol 1999; 173: 317-320.

34. Kaur AC, Dal H, Muezzinoglu B, Paksoy N. Idiopathic granulomatous mastitis. Report of a case diagnosed with fine needle aspiration cytology. Acta Cytolo 1999; 43: 481-484.

35. Erhan Y, Veral A, Kara E, Ozdemir N, Kapkac M, Ozdedeli E et al. A clinicopathologic study of a rare clinically entity mimicking breast carcinoma: idiopathic granulomatous mastitis. Breast J 2000; 9: 52-56.

36. Yip CH, Jayaram G, Swain M. The value of cytology in granulomatous mastitis: a report of 16 cases from Malaysia. Aust N Z J Surg 2000; 70: 103-105.

37. Goldberg J, Baute L, Storey L, Park P. Granulomatous mastitis in pregnancy. Obstet 
Gynecol 2000; 96: 813-815.

38. Pouchot J, Foucher E, Lino M, Barge J, Vinceneux P. Granulomatous mastitis: an uncommon cause of breast abscess. Arch Intern Med 2001; 161: 611-612.

39. Newnham MS, Shirley SE, MacDonald AH. Granulomatous lobular mastitis: a case report and review of the literature. West Indian Med J 2001; 50: 236-238.

40. Schelfout K, Tjalma WA, Cooremans ID, Coeman DC, Colpaert CG, Buytaert PM. Observations of an idiopathic granulomatous mastitis. Eur J Obstet Gynecol Reprod Biol 2001; 97: 260-262.

41. Poniecka AW, Krasuski P, Gal E, Lubin J, Howard L, Poppiti RJ. Granulomatous inflammation of the breast in a pregnant woman. : report of a case with : fine needle aspiration diagnosis. Acta Cytol 2001; 45: 797-801.

42. Yilmaz E, Lebe B, Usal C, Balci P. Mammographic and sonographic findings in the diagnosis of idiopathic granulomatous mastitis. Eur Radiol 2001; 11: 2236-2240.

43. Gal-Gombos EC, Esserman LE, Odzer SL, Weisberg S, Wilson C, Poppiti RJ. Granulomatous mastitis: diagnosis by Ultrasound-Guided core biopsy. Breast J 2001; 7: 129-130.

44. Sakurai T, Oura S, Tomino H, Yoshimazu T, Kokawa Y, Kinoshita T et al. A case of granulomatous mastitis mimicking carcinoma. Breast cancer 2002; 9: 265-268.

45. Al Nazer MA. Idiopathic granulomatous loblar mastitis: a forgotten clinical diagnosis. Saudi Med J 2003; 24: 1377-1380.

46. Hirata S, Saito T, Kiyanagi K, Kitada M, Yamazaki K, Sasajima T. et al. Granulomatous mastitis diagnosed by core-needle biopsy and successfully treated with corticosteroid therapy: a case report. Breast cancer 2003; 10: 378-381.

47. Azlina AF, Ariza Z, Arni T, Hisham AN. Chronic granulomatous mastitis: diagnostic and therapeutic considerations. World J Surg 2003; 27: 515-518.

48. Tuncbilek N, Karakas HM, Okten OO. Imaging of granulomatous mastitis: assessment of three cases. The Breast 2004; 13: 510-514.

49. Aldaqal SM. Idiopathic geanulomatous mastitis: clinical presentation, radiological 
features and treatment. Saudi Med J 2004; 25: 1884-1887.

50. Yaghan RJ. The magnetic resonance image findings of idiopathic granulomatous mastitis. Saudi Med J 2004; 25: 1715-1719.

51. Asoglu O, Ozmen V, Karanlik H, Tunaci M, Cabioglu N, Igci A et al. Feasibility of surgical management in patients with granulomatous mastitis. Breast J 2005; 2: 108-114.

52. Wilson JP, Massoll N, Marshall J, Foss RM, Copeland EM, Grobmyer SR. Idiopathic granulomatous mastitis: in search of a therapeutic paradigm. Am Surg 2007; 73: 798-802 


\section{Figure legends}

Fig 1. Histology of mammotome biopsy specimens. (a) Low power view highlights obvious lobular configuration of granulomatous inflammatory lesions (case 1). (b) Granulomatous lobulitis with multinucleated giant cells and atrophic terminal ducts (case 2). (c) Nodular granulomatous lesions were noted (case 3).

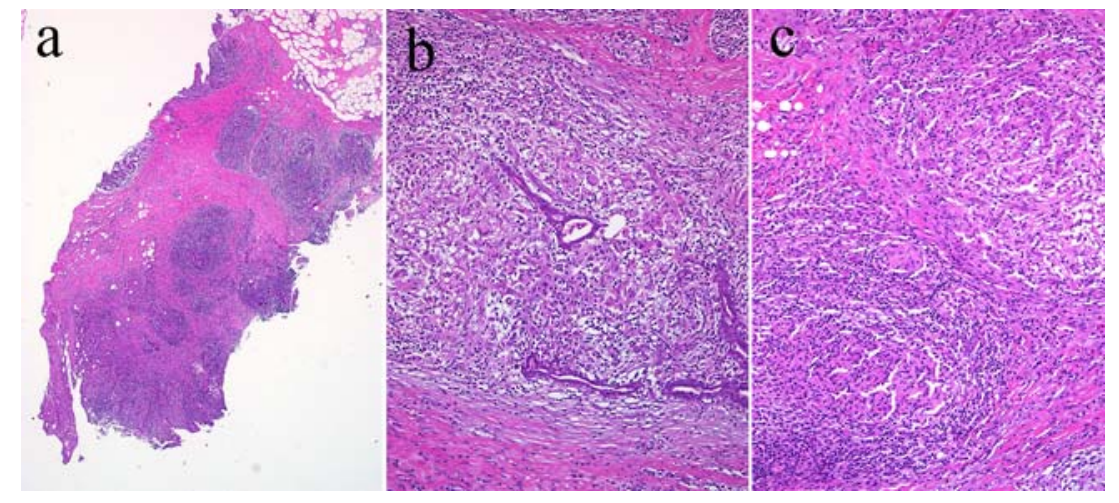

